\title{
THE ROLE OF PULSE STEROID THERAPY IN CASES OF METHANOL INDUCED OCULAR TOXICITY
}

\author{
Rehab A. Masoud"; Eman A. Khalifa** and Mohamed A. Kabeel*** \\ Forensic Medicine and Clinical Toxicology Department, Al-Azhr University*, Ain Shams \\ University**, \\ Ophthalmology Department, Ain Shams University***
}

\begin{abstract}
Methanol poisoning and toxic optic neuropathy is still seen in many parts of the developing world. In Egypt, it is one of the recorded cases in poison control centers especially among members of lower socioeconomic class. Particular vulnerability of the optic nerve and the retina; to toxic effect of methanol is known. The principle of steroid use is based on the postulation that blurring of vision in methanol poisoning could be following acute optic neuritis due to retrolaminar demyelination. The benefit has been proposed to be due to anti-inflammatory and immunosuppressant effect of steroids. Some authors objected to the effectiveness of this therapy. Aim of this study was to clarify the role of pulse steroid therapy in management of the victims of acute methanol poisoning who complained from visual defecit. Also, estimation of some prognostic factors for survival and final visual outcome was targeted. Methods: Prospective study carried out in poison control center (P.C.C.)of Ain Shams University Hospitals, 25 cases of acute methanol poisoned patients studied for history, complete ocular and systemic examination details, time to presentation, amount of alcohol ingested, and results of laboratory investigations, such as, arterial $\mathrm{pH}$, methanol levels, bicarbonate levels, and, therapy administered. Twelve patients of them, have been given pulse steroids. Visual acuity (VA), pupillary reaction, and fundus findings were assessed at presentation and 3 months after discharge. Statistical Analysis: Was done by chi square test, Fisher exact test\& independent t-test using SPSS 20 version software for studying the significance. Receiver operating characteristic curve (ROC) was used to assess the best cut off point with its area under curve (AUC), sensitivity, specificity, positive predictive value (PPV) and negative predictive value (NPV). Results \& Conclusion: Blood $\mathrm{pH}$ at admission is an excellent predictor for final visual outcome in methanol induced optic neuritis, with best cut off point: $\leq 7.06$ for poor outcome. Reactivity of pupils at admission was a significant prognostic factor, whereas reactive pupil means good visual outcome, and dilated non-reactive pupil predicts final deterioration and blindness .Two thirds of cases who received pulse steroid therapy had improved by the final follow up at 3 months, with a dramatic effect on fundus finding and visual acuity in some cases. Hemodialysis is a good treatment for methanol toxicity associated with decreased mortalities in a highly significant manner.
\end{abstract}

Key words: pulse steroid, methanol, optic neuritis, Blood $\mathrm{pH}$. 


\section{INTRODUCTION}

Methanol is one of the major adulterants of illicit liquor. Almost all cases of acute methanol toxicity result from ingestion. Suicidal ingestion of methanol containing products and unintended consumption of such products by children may occur. Methanol is cheaper than ethanol and may be used to fortify illicit spirits. Prisoners and others may substitute methanol-containing products for alcoholic beverages when ethanol is in short supply. Mass epidemics associated with these circumstances are reported from around the world (Shah et al., 2012). Rare cases of dermal (Karaduman et al., 2009) or inhalational toxicity are reported. Most inhalational exposures involve carburetor cleaner (Givens et al., 2008).

Small amounts of methanol may be taken with food. Dietary sources include fresh fruit and juices, vegetables, and dietary products containing aspartame. Methanol is also a natural fermentation product and small amounts are found in all spirits. Even in these small amounts it is thought to be a cause of a hangover (Calder, 1997). After binge drinking, serum methanol concentrations build up, but do not reach concentrations usually associated with acidosis and ophthalmological dysfunction

(Malandian and Cano, 1996). Cluster of infant deaths was reported due to topical application of methanol after a vaccination programme in Egypt (Darwish et al., 2002).

\section{Sources and Uses:}

Methanol is known as wood alcohol because it was distilled from wood in the1920s and 1930s. Today, almost all methanol is made synthetically by the catalytic reduction of carbon monoxide or carbon dioxide in the presence of hydrogen (IPCS, 1997).

The majority of it is used as a solvent, an intermediate in the manufacture of other chemicals, or as an octane booster in reformulated gasoline. It has an octane rating from 106 to 115 and has been advocated as a less polluting fuel. As a solvent, it is present in cleaning solutions, printing and duplicating solutions, adhesives, enamels, stains, dyes, varnishes, thinners, and paint removers. Many of these products are found in the home. It is also widely available as an antifreeze agent in windshield wiping fluids, a gas line antifreeze, a gasoline additive, and as a fuel for camp stoves and chafing dishes (Kinoshita et al., 2005).

\section{Absorption and metabolism:}

The absorption of methanol following oral administration is rapid with a mean absorption half-life of 5 minutes (Graw et al., 2000). Depending on the presence or absence of food, peak absorption occurs within 30-60minutes. Like other organic solvents, it is relatively well absorbed through the skin and also methanol is well absorbed by the inhalation route (Barceloux et al., 2002).

Methanol itself has relatively low toxicity. Metabolism is responsible for the transformation of methanol to its toxic metabolites. Methanol is metabolized in a sequential fashion, principally in the liver (Batterman et al., 1998). Alcohol dehydrogenase is the primary enzyme responsible for the oxidation of methanol to formaldehyde. The oxidation of formaldehyde to formic acid is facilitated by formaldehyde dehydrogenase (Brent et al., 2001). 
The conversion of formaldehyde to formic acid is very rapid with a half life of 1-2 minutes (Eells et al., 1981). It does not appear to be any accumulation of formaldehyde in the blood. Format metabolism is dependent upon the presence of tetrahydrofolate to form 10-formyl tetrahydrofolate that can be metabolized to carbon dioxide and water or alternative metabolic pathways (Haffner et al., 1997). The half-life of format has been as long as 20 hours in humans (Shahangian et al., 1984).

\section{Mechanisms of toxicity}

The Role of Formic Acid:

Methanol is metabolized to formaldehyde and then to formic acid. Although formaldehyde itself is potentially toxic, due to its rapid metabolism to formic acid, it has not been detected in body fluids after toxic methanol ingestions Formic acid is metabolized more slowly and, therefore, accumulates as the generation of formic acid exceeds the capacity to eliminate it (McMartin et al., 1980).

Tephly, (1991), found a direct correlation between formic acid accumulation and the toxicity of methanol. This was confirmed by Brent et al., (2001) who also identified a direct relationship between increased morbidity and mortality and the presence of high serum formic acid concentrations. There are a number of factors that control the rate of formic acid metabolism in humans. At physiological $\mathrm{pH}$, formic acid dissociates to format and a hydrogen ion. Format is subsequently metabolized to carbon dioxide and water by a folate-dependent mechanism. Format enters this metabolic cycle by combining with tetrahydrofolate to form 10-formyl tetrahydrofolate (Wiener, 2015).

Hence, the oxidation of format is dependent on hepatic tetrahydrofolate concentrations, which are controlled by two main factors. Firstly, the presence of adequate dietary folic acid (tetrahydrofolate is derived from folic acid), and secondly, the efficiency with which tetrahydrofolate is regenerated during format oxidation (Makar et al., 1990). Supplementation with folic acid enhances the oxidation of format in a variety of species including the monkey and in humans, and has been found to reduce the toxicity of methanol (Barceloux et al., 2002).

Formic acid inhibition of cytochrome oxidase

Formic acid can inhibit cytochrome c oxidase activity in intact mitochondria (Keyhani and Keyhani, 1980). The inhibition of cytochrome oxidase complex at the terminal end of the respiratory chain in the mitochondria leads to "histotoxic hypoxia." The binding of formic acid to cytochrome oxidase is similar to that seen with other toxins such as cyanide, hydrogen sulfide, and carbon monoxide, although formic acid is a less potent inhibitor (Erecinska and Wilson, 1980).

The inhibition of cytochrome oxidase by formic acid increases with decreasing $\mathrm{pH}$. This suggests that the active inhibitor is the undissociated acid as the concentration of the latter increases with fall in $\mathrm{pH}$ and as the inner membrane of the mitochondria is only permeable to the undissociated acid. Therefore, as the $\mathrm{pH}$ falls, cytochrome oxidase inhibition is potentiated and the onset of cellular injury is hastened (Liesivuori and Savolainen, 1991). 


\section{Etiology of Acidosis:}

Metabolic acidosis with an elevated anion gap is a hallmark of toxic alcohol poisoning. This is a consequence of the metabolism of the alcohols to toxic organic acids. The acids have no rapid natural metabolic pathway of elimination, and therefore they accumulate, unlike acetic acid resulting from ethanol metabolism, which can enter the Krebs cycle. In methanol poisoning, formic acid is responsible for the acidosis (Soghoian et al., 2009).

The accumulation of formic acid can cause an acidosis directly by delivering protons as it dissociates to format and hydrogen ions. As homeostatic mechanisms compensate for the increasing acidemia, the homeostatic reserve becomes exhausted so that the acidosis can no longer be compensated (Kavet and Nauss, 1990).

Lactate is produced as formic acid interferes with intracellular respiration and promotes anaerobic metabolism. As lactate concentrations rise and tissue hypoxia increases, the $\mathrm{pH}$ falls further and leads to the generation of more undissociated formic acid. A falling $\mathrm{pH}$ enhanced by lactate production will also increase formic acid diffusion across cell membranes leading to further central nervous system (CNS) depression with hypotension and increased lactate production. It has also been suggested that the severity of lactic acidosis may be increased due to the increased redox state of the body tissues with an increased ratio of $\mathrm{NADH}$ to NAD secondary to the oxidation of methanol and formaldehyde. The increase in the redox state would force conversion of pyruvate to lactate by stimulating anaerobic glycolysis (Meng et al., 2010).

Both format and lactic acid contribute to the anion gap increase seen in methanol poisoning. The early acidosis observed in methanol poisoning may be due to the accumulation of format, with lactate accumulation occurring in the later stages of poisoning from tissue hypoxia and inhibition of cellular respiration by formic acid (Sejersted et al., 1983).

Ocular Toxicity:

Ocular symptoms usually appear after a latent period of12-24 h following methanol ingestion (Ranjan et al., 2014). Optic neuritis, either retrobulbar or neuroretinitis is the well reported mode of presentation in cases of acute methanol poisoning (Shinya et al., 2003). Although it was suggested initially that formaldehyde was the causative agent in methanol ocular toxicity, in vivo studies have implicated formic acid (Sharpe et al., 1982).

Ocular toxicity appears to be caused by formic acid directly and not by the metabolic acidosis that accompanies its accumulation. However, acidosis can increase toxicity further by enabling greater diffusion of formic acid into cells. Vision can improve if acidosis is corrected as this produces larger amounts of dissociated formic acid that does not diffuse as easily as the undissociated formic acid (Barceloux et al., 2002).

Undissociated formic acid specifically targets the optic disc and retrolaminar section of the optic nerve, causing optic disc edema, breakdown of the myelin sheaths and optic nerve lesions. Retinal dysfunction occurs at lower formic acid concentrations than optic neuropathy (Hantson et al., 
1999). The undissociated formic acid binds to cytochrome oxidase causing histotoxic hypoxia, thereby inhibiting retinal and optic nerve mitochondrial function and depleting retinal and optic nerve ATP (Seme et al., 2001). The depletion of ATP reduces the activity of the membrane Na-K ATPase pump, which halts conduction of the action potential, damages the myelin sheaths and causes loss of vision. It also leads to stasis of axoplasmic flow that results in intra-axonal swelling and optic disc edema (Martin-Amat et al., 1977).

As myelin sheaths are damaged, they start to swell causing a compression-type injury to the nerve fibers. This prevents further axoplasmic flow of proteins, mitochondria and neurotubules from the cell body to the fiber of the axoplasm. As cells become deficient in these essentials they become more susceptible to formic acid induced injury, which causes neuronal conduction deficits and loss of vision. The selective damage to the retrolaminar optic nerve and retina may be caused by an increased exposure to formic acid due to a copious blood flow through the choriocapillaris and from the cerebral spinal fluid, thereby allowing formic acid to diffuse to the adjacent optic disc and the retrolaminar section of the optic nerve.

These cells are also selectively vulnerable to histotoxic hypoxia as optic nerve fibers and their myelin sheaths have fewer mitochondria and low reserves of cytochrome oxidase due to their low metabolic requirements (Barceloux et al., 2002).

Proteomic analysis of retinas in rats poisoned by methanol showed 24 proteins were different from baseline (14 increased, 10 decreased) (Chen et al., 2012), so the underlying pathophysiology of retinal toxicity from methanol may be more complex than is currently understood. Years after exposure, optic nerve atrophy, disc pallor and severe cupping may be still be present, even with normal intraocular pressure (Shin and Uhm, 2011).

Early investigators had tried lines of treatment for methanol induced ocular toxicity as spinal fluid exchange therapy, sweat baths, thyroid extracts, adrenocorticotrophin hormone, gastric lavage and alkali treatment without any significant clinical response (Kumar et al., 2003).

Ethanol and fomepizole have been used as specific antidotes to methanol in cases of toxicity. Both the agents block the conversion of methanol to formic acid, which is the active toxic metabolite. Bicarbonate administration and haemodialysis are used to correct the systemic acidosis caused by accumulation of formic acid. Folinic acid is administered to enhance the metabolism of formic acid already produced in the body. These forms of therapy prevent the formation of toxic metabolites and its subsequent catastrophic complications but do not have any significant value in treating established methanol induced ocular toxicity. Oral and parenteral steroids have been tried empirically by many investigators with varying results (Unnikrishnan and Raju, 2014). Some have suggested a possible benefit of corticosteroids for retinal injury following methanol poisoning (Wiener, 2015).

Intravenous pulse steroid therapy consists of administration of supraphysiological doses of glucocorticoids. It is useful in conditions where rapid anti- 
inflammatory effect is desired (Sinha and Bagga, 2008).

\section{Objectives:}

The present study aim is to clarify the therapeutic efficacy of pulse steroid therapy, and identify some predictors of survival and visual outcome.

\section{METHODOLOGY}

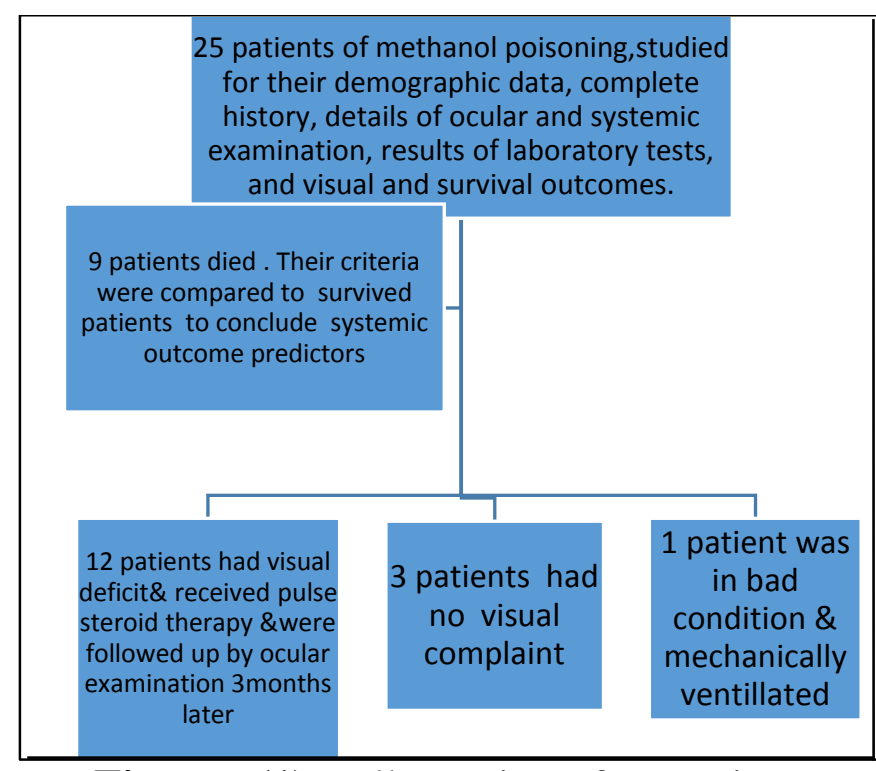

Figure (1): Illustration for patients inclusion in the current study

Twenty-five patient of acute methanol toxicity were admitted to poison control center of Ain Shams university hospitals during the period from May 2015 to the end of May 2016.

They were prospectively studied for their demographic data, complete history, details of ocular and systemic examination, results of laboratory tests, and visual and survival outcomes. The exclusion criteria were (diabetes mellitus, hypertension, osteoporosis, chronic renal failure).

All patients had history of either liquor consumption or methyl alcohol ingestion. Diagnosis is assured by detecting methanol blood level.

Ophthalmic examination included torch light examination to assess the pupillary reaction. Visual acuity was estimated using Snellen's chart and color vision using Ishihara chart. Visual field charting was done using perimeter and tangent screen. In cooperative patients, field charting was done by a Humphrey field analyzer. Intraocular pressure was assessed by the applanation tonometry.

All patients who received pulse steroid were subjected to retinal examination after dilating the pupil with tropicamide eye drops. Special attention was given to the presence of hyperemia, blurring of disc margin, disc edema, peripappillary edema and macular edema those patients were promptly treated as protocols of treatment in cases of methanol intoxication. All the patients were given I.V. infusion of $7.5 \%$ sodium bicarbonate $100 \mathrm{ml}$ fourth hourly. 25\% ethanol was given through Ryle's tube. Initially a $15 \mathrm{ml} / \mathrm{kg}$ bolus was given followed by $2-3 \quad \mathrm{ml} / \mathrm{kg} / \mathrm{hr}$ as maintenance infusion. The amount of sodium bicarbonate and ethanol administered were guided by the clinical condition of the patient, acidosis and plasma bicarbonate levels. Ryle's tube administration of ethanol and IV sodium bicarbonate were continued till the patients recovered completely.

All were given a loading doses of folinic acid $1 \mathrm{mg} / \mathrm{kg}$ ( $\max 50 \mathrm{mg} /$ dose) 6 hourly for 6 doses titrating with the patients response and $\mathrm{ABG}$ values. Later on it was changed to oral folinic acid $15 \mathrm{mg}$ 6hourly. Hemodialysis was done in patients with severe metabolic acidosis refractory to treatment, or serum methanol concentration $>50$ $\mathrm{mg} / \mathrm{dL}$, or visual signs and/or symptoms or kidney failure. 
I.V. corticosteroid not routinely given in the P.C.C. at which the study was carried out, its use is conflicting among toxicologist and expensive. So, for the purpose to evaluate the therapeutic role of high dose (pulse) steroids in methanol optic neuropathy, twelve patients of the study was given I.V steroids at dose of $1 \mathrm{gm} /$ day for 3days., followed by oral steroids $1 \mathrm{mg} / \mathrm{kg}$ for 10 days (as solupred $20 \mathrm{mg}$ tab) 3 times/day(Wiener,2015), Then the patients were followed up by ophthalmic examination after 3 months at Durrah specialized eye center. At follow-up pupillary reaction, visual acuity, color vision, visual field and detailed fundus evaluation were done in all patients.

The patients who received steroid therapy were under umbrella of antibiotics and $\mathrm{H} 2$ blocker ranitidine to prevent infection and gastric adverse effects.

\section{Ethical consecrations:}

Full informed consent was taken from the patients or their relatives for participating in the study, there was no additional financial burden for the patient in participating in the study.

\section{Statistical Analysis}

Data were collected, revised, coded and entered to the Statistical Package for Social Science (IBM SPSS) version 20. Qualitative data were presented as number and percentages while quantitative data were presented as mean, standard deviations and ranges.

The comparison between two groups with qualitative data were done by using Chi-square test and/or Fisher exact test Statistical Analysis: Was done by chi square test using SPSS 16 version software for studying the significance was used instead of Chisquare test when the expected count in any cell was found less than 5 .

The comparison between two groups regarding quantitative data with parametric distribution was done by using Independent t-test. Receiver operating characteristic curve (ROC) was used to assess the best cut off point with its area under curve (AUC), sensitivity, specificity, positive predictive value (PPV) and negative predictive value (NPV).

The confidence interval was set to $95 \%$ and the margin of error accepted was set to $5 \%$. So, the p-value was considered significant as the following:

$$
\begin{aligned}
& P>0.05: \text { Non significant } \\
& P<0.05: \text { Significant } \\
& P<0.01 \text { : Highly significant. }
\end{aligned}
$$

\section{RESULTS}

Twenty-five patients who admitted with history of methanol toxicity in P.C.C. of Ain Shams University hospitals were included in the study. Eighty eight percent $(88 \%)$ of those cases had visual complaint, while $12 \%$ of cases hadn't visual complaint.

Out of the 25 patients, 21 were male and 4 were female. The age of patients under study ranged from 17-46 years. Fifteen patients were between 17 and 29 years, while ten patients were between 30 and 46 years. All cases had delayed time not less than 2 days.

Fifty-eight percent $(58 \%)$ of visual disturbances was in the form of decreased visual acuity and $21 \%$ of patients complained from total blindness, while the other $21 \%$ of them complained from snow field vision. All visual deficit complaints were of sudden onset. Color vision was impaired in 2 cases.

The relation between pupillary reaction on admission with the final visual outcome was studied and it was 
found that pupillary reaction was a significant predictor for visual outcome. Normal pupillary reaction associated more with improved vision.
Reactivity of pupils was a good sign, while fixed pupils almost associated with bad prognosis regarding vision.

Table (1): Relation of pupillary reaction on admission with final visual outcome of methanol intoxicated cases in the current study

\begin{tabular}{|c|c|c|c|c|}
\hline \multirow{2}{*}{ Pupillary Reaction } & Improved vision & Not improved vision & \multicolumn{2}{|c|}{ Chi-square test } \\
\cline { 2 - 5 } & $\mathbf{\%}$ & $\mathbf{\%}$ & $\mathbf{X}^{\mathbf{2}}$ & P-value \\
\hline RRR (normal) & $66.67 \%$ & $14.29 \%$ & \multirow{3}{*}{$\mathbf{7 . 6 4 1}$} & \multirow{2}{*}{$\mathbf{0 . 0 2 1}$} \\
\hline Dilated \& reactive & $33.33 \%$ & $28.57 \%$ & & \\
\hline Dilated \& fixed & $0.00 \%$ & $57.14 \%$ & \\
\hline
\end{tabular}

Studying the relation of serum biomarkers on admission with final visual outcome, it was found that $\mathrm{pH}$ was the unparalleled prognostic factor for visual outcome, while blood methanol level \&sodium bicarbonate level were not well associated with the final outcome as shown in the table (1).

Table (2): Relation of important serum biomarkers with final visual outcome of methanol intoxicated cases in the current study

\begin{tabular}{|c|c|c|c|c|c|c|}
\hline \multirow{2}{*}{ Serum biomarkers } & \multicolumn{2}{|c|}{ Not improved vision } & \multicolumn{2}{c|}{ Improved vision } & \multicolumn{2}{c|}{ Independent t-test } \\
\cline { 2 - 7 } & Mean & SD & Mean & SD & T & p-value \\
\hline Blood methanol level & 88.00 & 56.50 & 128.17 & 93.74 & -0.799 & 0.438 \\
\hline $\mathrm{pH}$ on admission & 6.93 & 0.22 & 7.17 & 0.15 & -2.396 & 0.031 \\
\hline NaHCO3 & 4.95 & 2.19 & 7.60 & 4.38 & -1.143 & 0.272 \\
\hline
\end{tabular}

For accurate use of this important predictor for visual outcome in methanol toxicity, ROC curve was used to assess the best cut off point in metabolic acidosis in those patients. It was $\leq 7.06$ means bad visual prognosis, while increasing $\mathrm{PH}$ above 7.06 outweigh vision improvement. 


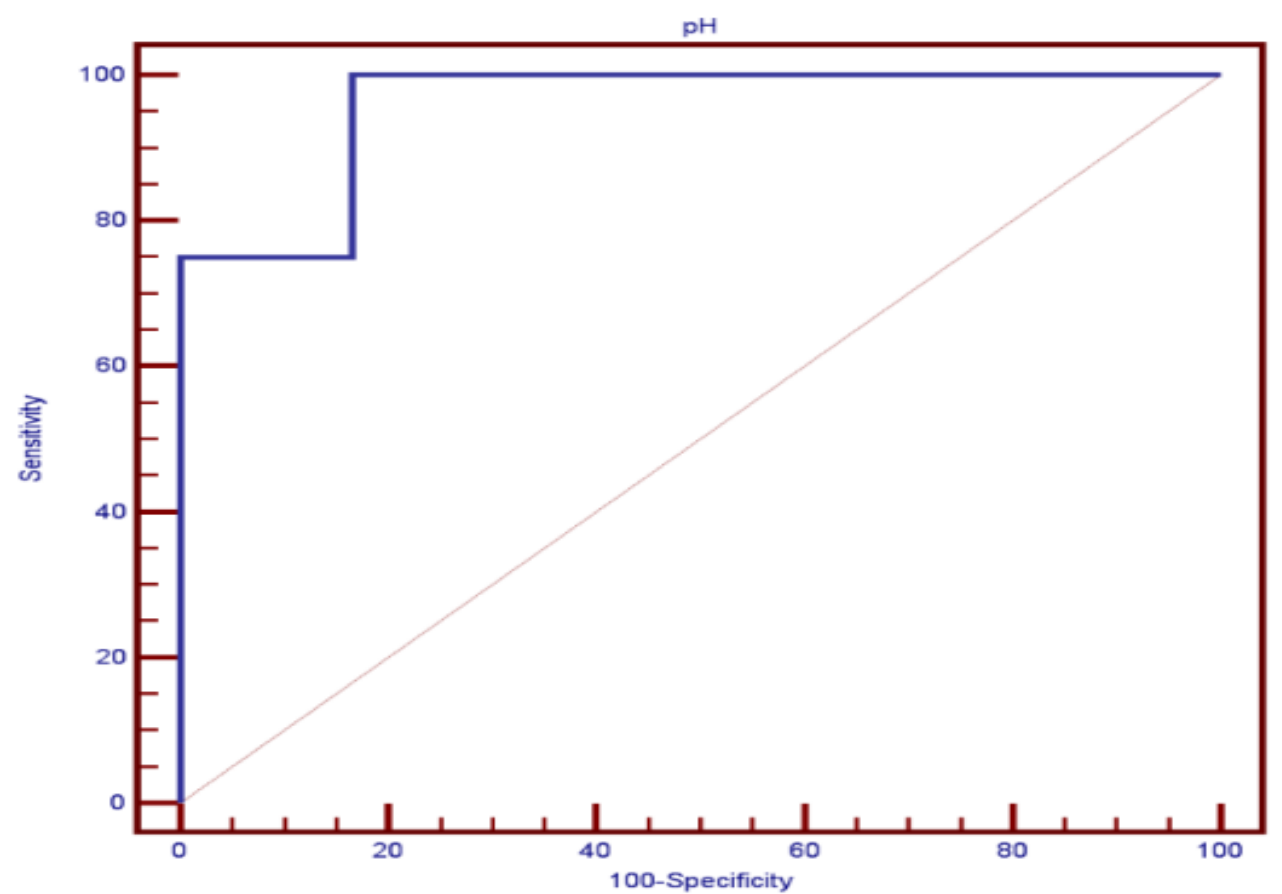

\begin{tabular}{|l|l|l|l|l|l|}
\hline Cut off point & AUC & Sensitivity & Specificity & +PV & -PV \\
\hline$<7.06$ & 0.958 & 100.00 & 83.33 & 66.7 & 100.0 \\
\hline
\end{tabular}

Figure (2): Receiver operating characteristic curve (ROC) for $\mathrm{pH}$ level in differentiation between improved vision and blindness in vision outcome in methanol induced optic neuropathy

The accuracy of this laboratory test is measured by the area under the curve (AUC), it was 0.95 which means excellent prediction.

By fundus examination on admission, optic disc changes were noted, disc oedema occurred in $21 \%$, peripapillities in $14 \%$, hyperemia in $0.07 \%$, neuroretinities in $14 \%$, while no abnormality detected (NAD) in
$35 \%$.On follow up, fundus examination either revealed optic atrophy or normalization of the disc but this not well correlated clinically especially in those who received pulse steroid therapy in whom vision improved despite non promising fundus finding, this is may be attributed to improve quality of vision.

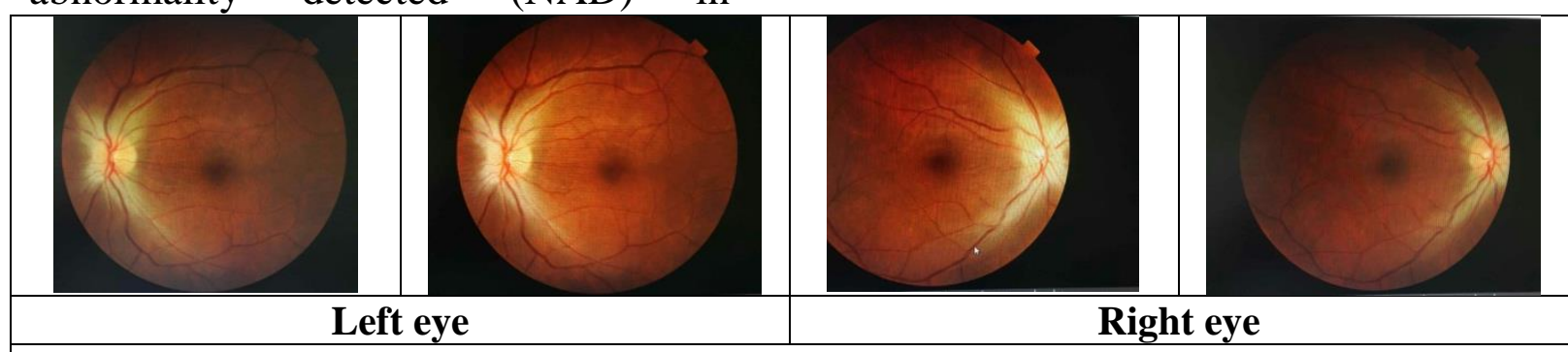

Figure (3): Coloured fundus photo for one case reveals peripapilary retinal nerve fiber layer infarction at presentation by methanol toxicity. The patient manifested a visual acuity of $\mathrm{CF}$ at $75 \mathrm{~cm}$ in right eye, $\mathrm{CF}$ at $50 \mathrm{~cm}$ in left eye and pupil is dilated and sluggish.After administration of pulse steroid therapy, on follow up three months later, the patients improved to $6 / 12$ in both eyes and pupillary reflex was normal and no abnormality detected in fundus examination 
Using pulse steroid therapy had a positive effect on improving vision even in severe cases. Eight out of twelve patients who received it recorded improvement as shown in the following table.

Table (3): Visual status of methanol intoxicated patients who received pulse steroid therapy in the current study

\begin{tabular}{|c|c|c|c|c|c|c|c|c|}
\hline \multirow[t]{2}{*}{ Cases } & \multirow{2}{*}{$\begin{array}{c}\text { Time interval } \\
\text { between } \\
\text { Alcohol } \\
\text { consumption } \\
\text { \& start of } \\
\text { Treatment in } \\
\text { days }\end{array}$} & \multicolumn{2}{|c|}{$\begin{array}{l}\text { Visual acuity } \\
\text { on admission }\end{array}$} & \multirow[t]{2}{*}{$\begin{array}{c}\text { Fundus } \\
\text { examination } \\
\text { on admission }\end{array}$} & \multicolumn{2}{|c|}{$\begin{array}{c}\text { Visual acuity } \\
\text { after } \\
\text { 3monthhs }\end{array}$} & \multirow{2}{*}{$\begin{array}{c}\text { Fundus } \\
\text { examinatio } \\
\text { n after } 3 \\
\text { months }\end{array}$} & \multirow[t]{2}{*}{$\begin{array}{c}\text { Vision } \\
\text { Outcome }\end{array}$} \\
\hline & & Right & Left & & $\begin{array}{c}\text { Rig } \\
\text { ht }\end{array}$ & Left & & \\
\hline $\begin{array}{c}\text { Case } \\
\text { (1) }\end{array}$ & 8 & 0.3 & HM & Normal optic disc & 0.4 & 0.1 & $\begin{array}{c}\text { Optic } \\
\text { atrophy } \\
\text { Severe } \\
\text { concentric } \\
\text { contraction }\end{array}$ & $\begin{array}{c}\text { Mild } \\
\text { improvem } \\
\text { ent }\end{array}$ \\
\hline $\begin{array}{l}\text { Case } \\
\text { (2) }\end{array}$ & 2.5 & $\begin{array}{l}\text { CF at } \\
3 \mathrm{~m}\end{array}$ & $\begin{array}{c}\text { CF at } \\
3 \mathrm{~m}\end{array}$ & $\begin{array}{l}\text { Defective color } \\
\text { vision }\end{array}$ & 0.7 & 0.7 & $\begin{array}{c}\text { Normal } \\
\text { optic disc }\end{array}$ & Improved \\
\hline $\begin{array}{c}\text { Case } \\
\text { (3) }\end{array}$ & 2.5 & $\begin{array}{l}\text { CF at } \\
75 \mathrm{~cm}\end{array}$ & $\begin{array}{l}\mathrm{CF} \text { at } \\
25 \mathrm{~cm}\end{array}$ & $\begin{array}{c}\text { Bilateral } \\
\text { papillities } \\
\text {,neuroretinitis } \\
\text { decrease colour } \\
\text { vision }\end{array}$ & $6 / 12$ & $6 / 12$ & $\begin{array}{l}\text { Normal } \\
\text { fundus }\end{array}$ & Improved \\
\hline $\begin{array}{c}\text { Case } \\
\text { (4) }\end{array}$ & 3 & NPL & NPL & $\begin{array}{c}\text { Pallid disc } \\
\text { oedema }\end{array}$ & NPL & NPL & $\begin{array}{c}\text { Optic } \\
\text { atrophy }\end{array}$ & $\begin{array}{c}\text { Not } \\
\text { improved }\end{array}$ \\
\hline $\begin{array}{c}\text { Case } \\
\text { (5) }\end{array}$ & 4 & HM & HM & $\begin{array}{l}\text { ILL defriend disc } \\
\text { margin, } \\
\text { hyperemia \& } \\
\text { oedema around } \\
\text { disc, peripapillary } \\
\text { retinal ischemia }\end{array}$ & $\begin{array}{l}\mathrm{CF} \\
\text { at } 70 \\
\mathrm{~cm}\end{array}$ & $1 / 60$ & $\begin{array}{l}\text { Primary } \\
\text { optic } \\
\text { atrophy }\end{array}$ & Improved \\
\hline $\begin{array}{c}\text { Case } \\
(6)\end{array}$ & 3 & HM & $2 / 60$ & $\begin{array}{c}\text { Pallid disc } \\
\text { oedema }\end{array}$ & HM & $1 / 60$ & $\begin{array}{l}\text { Optic } \\
\text { atrophy }\end{array}$ & $\begin{array}{c}\text { Not } \\
\text { improved }\end{array}$ \\
\hline $\begin{array}{c}\text { Case } \\
\text { (7) }\end{array}$ & 3 & $\begin{array}{l}\text { CF at } \\
50 \mathrm{~cm}\end{array}$ & $\begin{array}{l}\text { CF at } \\
70 \mathrm{~cm}\end{array}$ & $\begin{array}{c}\text { bilateral } \\
\text { Disc oedema }\end{array}$ & $2 / 60$ & PL & $\begin{array}{c}\text { Optic } \\
\text { atrophy not } \\
\text { involving } \\
\text { whole disc } \\
\text { in Rt } \\
\text { eye.C/D:0.5 } \\
\text { \& involving } \\
\text { whole disc } \\
\text { in Lt } \\
\text { eye.C/D:0.9 }\end{array}$ & $\begin{array}{c}\text { Improved } \\
\text { right eye } \\
\text { \& worsed } \\
\text { left one }\end{array}$ \\
\hline $\begin{array}{c}\text { Case } \\
(8)\end{array}$ & 2 & $6 / 60$ & $\begin{array}{l}\mathrm{CF} \text { at } \\
50 \mathrm{~cm}\end{array}$ & NAD & $6 / 36$ & $6 / 36$ & $\begin{array}{c}\text { Normal } \\
\text { Disc }\end{array}$ & Improved \\
\hline $\begin{array}{c}\text { Case } \\
\text { (9) }\end{array}$ & 3 & $6 / 60$ & $\begin{array}{l}\text { CF at } \\
50 \mathrm{~cm}\end{array}$ & NAD & $6 / 12$ & $6 / 60$ & $\begin{array}{l}\text { Normal } \\
\text { Disc }\end{array}$ & Improved \\
\hline
\end{tabular}




\begin{tabular}{|c|c|c|c|c|c|c|c|c|}
\hline $\begin{array}{c}\text { Case } \\
(10)\end{array}$ & 3 & NPL & NPL & $\begin{array}{c}\text { Bilateral } \\
\text { papilloedema } \\
\text { elongated disc } \\
\text { margin. }\end{array}$ & $6 / 36$ & $6 / 12$ & $\begin{array}{c}\text { Normal } \\
\text { disc. }\end{array}$ & Improved \\
\hline $\begin{array}{c}\text { Case } \\
(11)\end{array}$ & 4 & $\begin{array}{c}\text { CF at } \\
50 \mathrm{~cm}\end{array}$ & $3 / 60$ & $\begin{array}{c}\text { Bilateral optic } \\
\text { neuritis }\end{array}$ & $\mathrm{HM}$ & $6 / 60$ & $\begin{array}{c}\text { Pale disc . } \\
\text { Optic } \\
\text { atrophy. }\end{array}$ & $\begin{array}{c}\text { Initial, } \\
\text { then } \\
\text { partial } \\
\text { improve- } \\
\text { ment, }\end{array}$ \\
\hline $\begin{array}{c}\text { Case } \\
(\mathbf{1 2})\end{array}$ & 4 & $1 / 60$ & $1 / 60$ & $\begin{array}{c}\text { Peripapillary } \\
\text { oedema \&disc } \\
\text { oedema. }\end{array}$ & $6 / 36$ & $6 / 36$ & $\begin{array}{c}\text { Restored } \\
\text { disc margin }\end{array}$ & Improved \\
\hline
\end{tabular}

NAD: no abnormality detected

NPL: no perception of light

$\mathrm{CF}$ : counting finger

HM: hand movement

C/D: cup to disc ratio

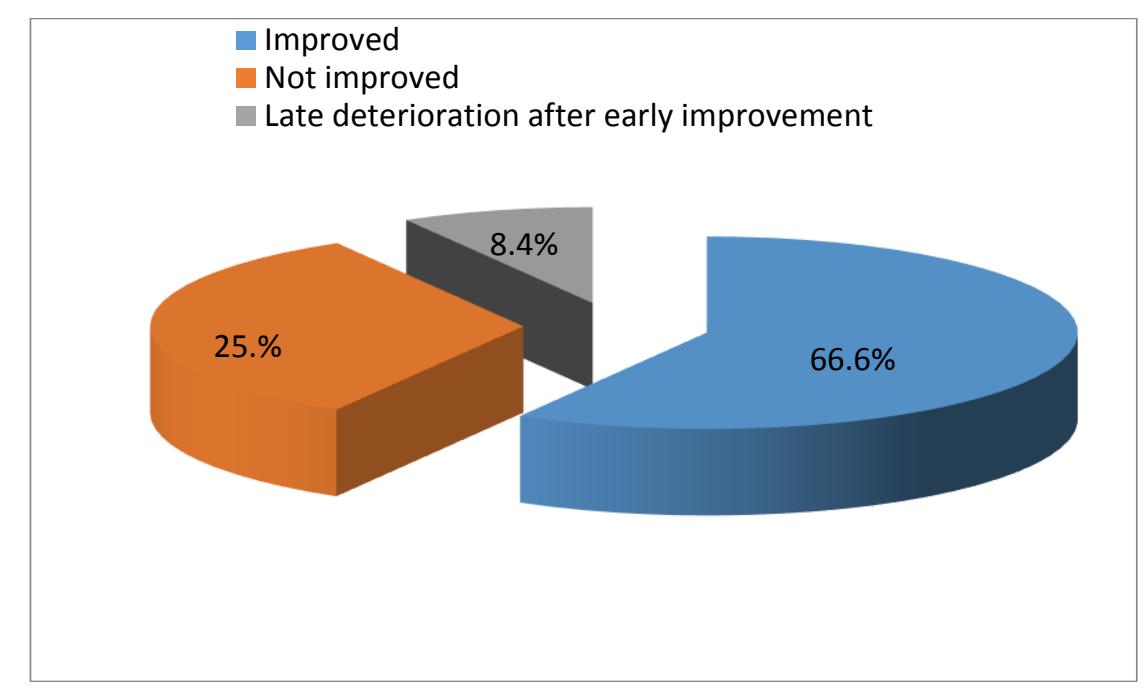

Figure (4): Final visual outcome at 3 months of patients of methanol optic neuropathy after administration of pulse steroid therapy.

The only case who had visual deficit and didn't receive pulse steroids due to bad condition, has recovered and unfortunately, he became blind.

Nine of patients died after variable periods of hospital stay, characters of them were compared to that of survived patients as shown in table (4), these included: delay time in days, amount of alcohol consumption (in $\mathrm{ml}$ ), blood gases at admission, the neurological state of the patients and weather hemodialysis was done or not.

$\mathrm{pH}$ at admission was highly significantly different between the two groups $(\mathrm{p}<0.001)$ as metabolic acidosis was diagnosed clinically and chemically in all of the patients, but the more acidotic patients died, in those patients $\mathrm{pH}$ ranged from $(6.78-7.1)$ while in survived patients $\mathrm{pH}$ ranged from $(6.8-7.47)$.

Other characteristic feature which affect significantly the survival outcome was hemodialysis $(\mathrm{p}<0.01)$, as those patients who have conducted dialysis, had obviously better prognosis. 
Another significant factor affect the prognosis, was the neurological status, as the coma alone or with convulsions had a bad prognostic indication. Clinically; seizures were a very poor prognostic sign.

Table (4): Comparison between non-survivors and survivors of methanol-intoxicated cases in the current study regarding some intoxication and clinical data

\begin{tabular}{|l|c|c|c|c|}
\hline & Non survivors & Survivors & \multicolumn{2}{c|}{$\begin{array}{c}\text { Independent t- } \\
\text { test }\end{array}$} \\
\cline { 3 - 5 } & & & t & P-value \\
\hline Delay time (days) & $1.08 \pm 0.53$ & $1.81 \pm 0.93$ & 1.932 & 0.068 \\
\hline $\begin{array}{l}\text { Amount of ingested liquor } \\
(\mathrm{ml})\end{array}$ & $433.33 \pm$ & $345.00 \pm$ & -0.498 & 0.634 \\
\hline Methanol level in blood & 115.47 & 287.94 & & \\
\hline pH on admission & $158.41 \pm 98.78$ & $114.67 \pm 87.92$ & -1.161 & 0.258 \\
\hline NaHCO3 & $6.90 \pm 0.13$ & $7.18 \pm 0.21$ & 3.748 & 0.001 \\
\hline Coma & $5.19 \pm 3.09$ & $7.18 \pm 4.08$ & 1.310 & 0.203 \\
Coma + Seizur & $5(55.6 \%)$ & $3(20.0 \%)$ & 13.341 & 0.010 \\
Heamodialysis & $2(22.2 \%)$ & $0(0.0 \%)$ & & \\
\hline
\end{tabular}

\section{DISCUSSION}

Methanol poisoning is an acute medical emergency. Particular vulnerability of the optic nerve and the retina; to toxic effect of methanol is known (Plaziac et al., 2003). $84 \%$ of the cases of this study were male, $66 \%$ of them were alcoholic, (25\%) were suicidal and only (9\%) were accidental ingestion of methanol. Unnikrishnan and Raju, (2014) reported a study from India in which all cases were male and alcoholic.

By studying the prognostic criteria for visual outcome in methanolintoxicated cases, pupillary reactivity was a significant predictor. Also, Unnikrishnan and Raju, (2014) studied pupillary involvement correlation with visual acuity at presentation and they found it is associated significantly with decreased vision.

This is may be because optic nerve is the afferent nerve for pupil light reflex. Bremner, (2004) strengthen this suggestion when he stated that reflexes are extensively used in clinical neurology to assess function in sensory or motor nerves. Reflexes are involuntary and therefore serve as objective indicators of function. The optic nerve forms the afferent limb of a number of brainstem reflexes that could potentially be exploited when testing its function, but the most useful has proved to be the pupil light reflex (PLR): the PLR can be easily observed, causes no distress or discomfort to the patient, and may be quantified according to serum biomarkers, methanol blood level was found to be insignificant in prediction of systemic or visual outcome in the current study, this is may be due to probability of presence of ethanol mixture by different concentrations in the consumed liquors by the patients, also nutritional status which varied among cases as reported by Shinto Francis et al., (2016) who stated that poor nutritional status appears to be poor prognostic indicator possibly suggesting coexisting folic acid and 
multivitamin deficiency.

In the current study, $\mathrm{pH}$ level was the unique marker for prediction for both survival and visual outcome this was in agreement with Desai et al., (2013) who conducted a retrospective study on methanol-poisoned patients and stated that the degree of acidosis at presentation appears to determine final visual acuity and $\mathrm{pH}$ was the strongest predictor of it.

This explained by Joseph et al., (2004), they stated that format does damage in a media of high-anion-gap metabolic acidosis. More importantly, it is a direct inhibitor of the mitochondrial cytochrome oxidase by disrupting the oxidative process occurring in the respiratory chain. This leads to anoxia, which is more pronounced in areas of high ATP dependence like the optic nerve and retina. Anoxia leads to membrane disruption leading to the morphologic changes noted on the level of the mitochondria. Acidosis aggravates these damaging as protons increase the production of membrane- reactive oxygen species as well as the influx of $\mathrm{Ca}++$ through membranes.

$\mathrm{NaHCO} 3$ didn't appear to be a significant predictor statistically although it was significant clinically. According to the criteria of survived patients, haemodialysis was a significant treatment which decrease bad outcome may be due to elimination of the alcohol and correction of acidosis and this is the corner stone in methanol treatment.

By direct fundoscope, fundal abnormalities were disc oedema, disc hyperemia, peripapillities and neuroretinities. All these abnormalities have affirmed by ophthalmologists to be heal by optic atrophy and therefore blindness will be the net result, but in fact some cases of this study had unsuspected resolved fundus changes and even other cases with diagnosed optic atrophy at follow up had improved visual acuity. The explanation isn't clear, may be explained by understanding what is called [Quality of vision] (QoV) which is a subjective entity based on an individual's unique perception of his or her vision. This perception is multifactorial, consisting not only of visual factors but also of psychological factors. Although optics and vision can be easily measured, none of these measurements explain how the patient subjectively perceives his or her vision; they provide only an indication. Two patients may have identical visual function in terms of objective and subjective testing but very different perception of their QoV. Eye disease, refractive surgery, spectacles, and contact lenses may change QoV (McAlinden et al., 2010).

These findings may agree with the conclusion of Zadeh et al., (2011) who stated that; long-term outcomes of retinal toxicity are difficult to predict.

Some cases (as case:1,8,9) had affected vision in spite normal fundus appearance, this was in agreement with Desai et al., (2013) who stated that the possibility of retrobulbar neuritis, which can manifest with a normallooking fundus and can recover completely make patients with a history of spurious liquor ingestion and a concern of visual disturbances should be treated for alcohol poisoning in the appropriate manner, even if the fundus appears normal.

As regard delay time, there was no wide variation in those patients, most of them came two days after 
consumption of methanol due to sudden decrease of visual acuity, and it was insignificant variable in comparing survived and died patients.

The time passed between poisoning and receiving pulse steroid therapy ranged from 2 to 4 days only, so it didn't differ in vision outcome, except one case came by referral from other hospital so he received pulse steroid after 8 days that patient suffered from late deterioration after initial improvement in visual acuity. Shukla et al., (2006) tried I.V. methylprednisolone in 17 cases of methanol toxicity and reported that the time of starting treatment after alcohol consumption which varied from 6 to 45 days, had no effect on the final visual outcome and 3 patients who reported for treatment after more than one month after alcohol intake also had a good visual recovery.

\section{CONCLUSION}

The present study found that intravenous pulse steroid therapy has a beneficial role in the management of cases of methyl alcohol poisoning presenting with decreased visual acuity or complete blindness. Most eyes showed visual improvement at 3 months.

Pupillary reaction is a good test for assessment of eye involvement and can predict final visual outcome in methanol intoxicated patients. Also, degree of $\mathrm{pH}$ on admission can predict it with best cut off point $>7.06$ for good visual outcome. Haemodialysis treatment associates more with survival. Occurrence of coma, convulsions or both can significantly predict death in methanol poisoned patients.

\section{RECOMMENDATIONS}

- The current study recommend all patients of methanol poisoning to be treated by pulse steroid therapy irrespective of the amount of visual defecit and the time of presentation.

- Insure the importance of hemodialysis in improving survival and visual outcome

- The present study clarify important predictors for visual outcome in methanol poisoned patients like pupillary light reflex and degree of $\mathrm{pH}$, the application of these predictors is advised for early aggressive treatment for better visual outcome

\section{REFERENCES}

Barceloux DG, Bond GR, Krenzelok EP, et al (2002): American Academy of Clinical Toxicology practice guidelines on the treatment of methanol poisoning. $\mathrm{J}$ Toxicol Clin Toxicol; 40: 415-446.

Batterman SA, Franzblau A, D'Arcy JB, et al (1998): Breath, Urine, and Blood Measurements as Biological Exposure Indices of Short-Term Inhalation Exposure to Methanol. Int. Arch. Occup. Environ. Health; 71:325-335.

Bremner FD (2004): Pupil assessment in optic nerve disorders Cambridge Ophthalmological Symposium Eye; 18:1175-1181.

Brent J, McMartin K, Phillips S, et al (2001):Fomepizole for the Treatment of Methanol Poisoning. N. Engl J Med.; 344:424-429.

Calder I (1997): Hangovers-Not the Ethanol-Perhaps the Methanol. Br Med J.; 314: 2-3.

Chen JM, Zhu GY, Xia WT, et al (2012): Proteomic analysis of rat retina after methanol intoxication. Toxicology; 293:89-96. 
Darwish A, Roth CE, Duclos P, et al (2002): Investigation into a cluster of infant deaths following immunization: evidence for methanol intoxication.

Vaccination; 20, 3585-3589.

Desai T, Sudhalkar A, Vyas U, et al (2013): Methanol poisoning Predictors of outcome JAMA Ophthalmol; 131(3):358-64.

Eells JT, McMartin KE, Black K, et al (1981): Formaldehyde Poisoning. Rapid Metabolism to Formic Acid. J. Am. Med. Assoc.; 246:1237-1238.

Erecinska M, Wilson DF (1980): Inhibitors of Cytochrome c Oxidase. Pharmacol. Ther.; 8:1-10.

Givens M, Kalbfleisch K, Bryson S (2008): Comparison of methanol exposure routes reported to Texas poison control centers. West $\mathbf{J}$ Emerg Med.;9:150-153

Graw, M, Haffner H-T, Althaus L, et al (2000): Invasion and Distribution of Methanol. Arch. Toxicol., 74, 313-321.

Haffner HT, Besserer K, Graw M, et al (1997): Methanol Elimination in Non-alcoholics: Inter- and Intraindividual Variation. Forensic Sci Int.; 86:69-76.

Hantson P, De Tourtchaninoff $M$, Simoens G, et al (1999): Evoked Potentials Investigation of Visual Dysfunction after Methanol Poisoning. Crit Care Med.; 27:2707-2715.

Hayreh MS, Hayreh SS, Baumbach GL, et al (1977): Methyl Alcohol Poisoning III. Ocular Toxicity. Arch. Ophthalmol.; 95:1851-1858.

IPCS (1997): Health and Safety Guide No. 105. Methanol; World Health Organization: Geneva,; 105.
Karaduman F, Asil T, Balci K, et al (2009): Bilateral basal ganglionic lesions due to transdermal methanol intoxication. J Clin Neurosci.;16:1504-1506

Kavet, R.; Nauss, K.M (1990): The Toxicity of Inhaled Methanol Vapors. Crit. Rev. Toxicol., 21; 21-50.

Joseph M. Ranche, MD, Raul D (2004): Cruz, MD, et al. Methanol induced bilateral optic neuropathy. Philippine Journal of Ophthalmology;29(4)*

Keyhani J, Keyhani E(1980): EPR Study of the Effect of Formate on Cytochrome c Oxidase. Biochem. Biophys. Res. Commun.; 92;327333.

Kinoshita H, Nishiguchi M, Ouchi H, et al (2005): Methanol: toxicity of the solvent in a commercial product should also be considered. Hum Exp Toxicol.;24:663.

Kumar SS, Seerala Boopathy K, Bhaskaran ME (2003): Methanol poisoning - A Chennai experience. J Assoc Physicians India; 51:425-6.

Liesivuori J, Savolainen H (1991): Methanol and Formic Acid Toxicity: Biochemical Mechanisms. Pharmacol. Toxicol.; 69:157-163.

Makar AB, Tephly TR, Sahin G, et al (1990): Format Metabolism in Young Swine. Toxicol Appl Pharmacol.; 105:315-320.

Malandain H, Cano Y (1996): Serum Methanol in the Absence of Methanol Ingestion. Ann Emerg Med.; 28:102-103.

Martin-Amat G, Tephly TR, McMartin KE, et al (1977): Methyl Alcohol Poisoning. II. Development of a Model for 
Ocular Toxicity in Methyl Alcohol Poisoning Using the Rhesus Monkey. Arch. Ophthalmol.; 95:1847-1850.

McAlinden C, Pesudovs K, Moore JE (2010): The Development of an Instrument to Measure Quality of Vision: The Quality of Vision (QoV) Questionnaire. Invest. Ophthalmol. Vis. Sci.; 51(11):5537-5545.

McMartin KE, Ambre JJ, Tephly TR (1980): Methanol Poisoning in Human Subjects. Role for Formic Acid Accumulation in the Metabolic Acidosis. Am J Med.; 68:414-418.

Meng QH, Adeli K, Zello GA, et al (2010): $\quad$ Elevated lactate in ethylene glycol poisoning: true or false? Clin Chim Acta.;411:601604.

Plaziac C, Lachapelle P, Camanova C (2003): $\quad$ Effects of methanol on the retinal function of juvenile rates. Neurotoxicology; 24: 255-260.

Ranche JM, MD, Cruz RD, Inocencio FP (2004): Methanol induced bilateral optic neuropathy. Philippine J Ophthalmol.;29(4):211-219.

Ratnesh Ranjan,Rajnath Kushwaha,Ramesh Chandra Gupta,et al (2014): An Unusual Case of Bilateral Multifocal Retinal Pigment Epithelial Detachment with Methanol-Induced Optic Neuritis.J.Med.Toxicol.;10:57-60.

Sanaei-Zadeh H, Zamani N, Shadnia S (2011): $\quad$ Outcomes of visual disturbances after methanol poisoning. Clin Toxicol.;49:102107.

Sejersted OM, Jacobsen D, Øvrebø
S, et al (1983): $\quad$ Formate

Concentrations in Plasma from Patients Poisoned with Methanol. Acta Med Scand.; 213:105-110.

Seme MT, Summerfelt P, Neitz J, et al (2001):

Differential Recovery of Retinal Function after Mitochondrial Inhibition by Methanol Intoxication. Investig. Ophthalmol. Vis. Sci.; 42:834-841.

Shah S, Pandey V, Thakore N, et al (2012): $\quad$ Study of 63 cases of methyl alcohol poisoning (hooch tragedy in Ahmedabad). J Assoc Physicians India.;60:34-36.

Shahangian S, Robinson VL, Jennison TA (1984):

Format Concentrations in a Case of Methanol Ingestion. Clin. Chem.; 30:1413-1414.

Sharpe JA, Hostovsky M, Bilbao JM, et al (1982): Methanol

Optic Neuropathy: A Histopathological Study. Neurology; 32:1093-1100.

Shin YW, Uhm KB (2011): A case of optic nerve atrophy with severe disc cupping after methanol poisoning. Korean

Ophthalmol.;25:146-150.

Francis S. T, Jyotish Nair R, Shiji PV, et al (2016): $\quad$ A case Series of Acute Methanol Poisoning from Northern Kerala. Emergency Med; 6(2): 1-3.

Shinya H, Hoshino K, Kiritohshi M, et al (2003): $\quad 2$ cases of acute retrobulbar neuritis by thinner inhalation; detected methanol of high concentration in gas phase assay. Chudoku Kenkyu 16:329-333

Shukla M, Shikoh I, Saleem A (2006): Intravenous methylprednisolone could salvage vision in methyl alcohol poisoning. 
Indian J Ophthalmol; 54(1):68-69.

Sinha A and Bagga A (2008): Pulse steroid therapy. Indian $\mathbf{J}$ Pediatr.; 75(10):1057-66.

Soghoian S, Sinert R, Wiener SW, et al (2009): $\quad$ Ethylene glycol toxicity presenting with non-anion gap metabolic acidosis. Basic Clin Pharmacol Toxicol.;104: 22-26.

Tephly TR (1991): The Toxicity of Methanol. Life Sci.; 48:1031-1041.
Unnikrishnan S, Raju KV (2014):

Clinico-biochemical correlation of ocular manifestations and visual prognosis in victims of hooch tragedy. J Clin Ophthalmol Research; 2(2):87-92.

Wiener S (2015): Toxic alcohols.In: "Goldfrank's Manual of Toxicologic Emergencies". Hoffman RS, editor. Tenth ed, United States of America; chapter109:; 3275-3303. 


\section{الملخص العربيى}

\section{دور العلاج بالاسترويد فى حالات اصابات العين الناتجة عن التسمم بالميثاتول

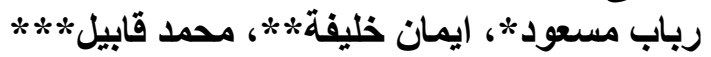

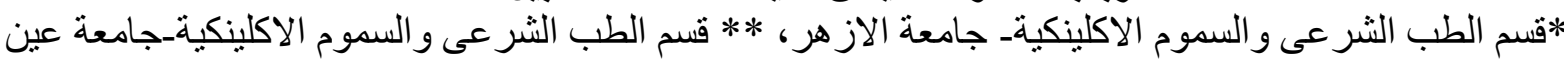

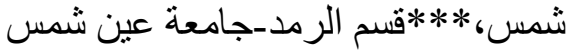

لا يز ال التسمم بالميثانول و الاعتلال العصبي البصري السام ظاهرة في العديد من أنحاء العالم النامي. في

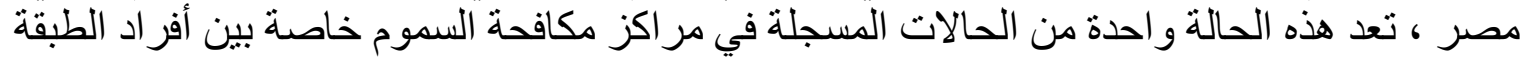

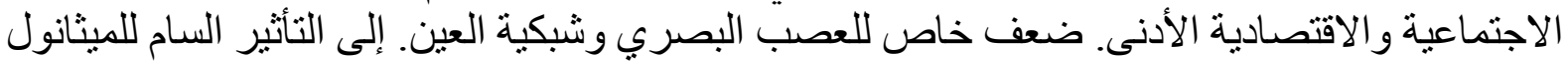

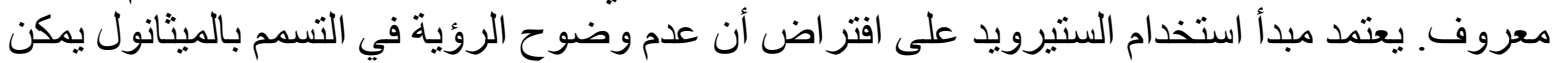

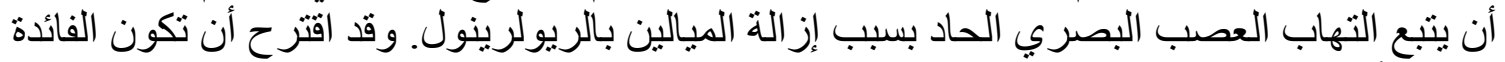

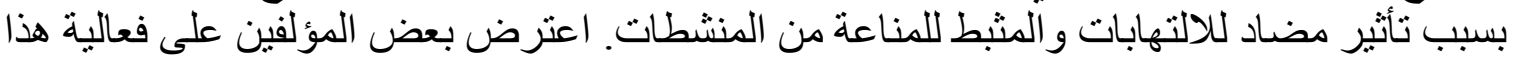

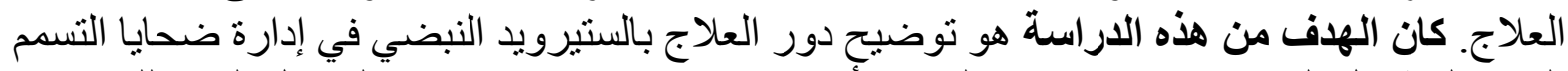

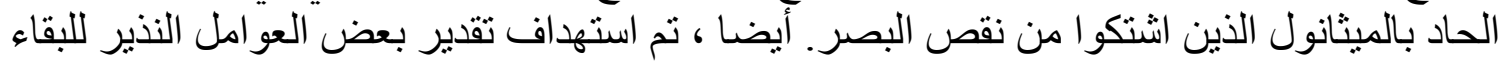
و النتيجة البصرية النهائية.

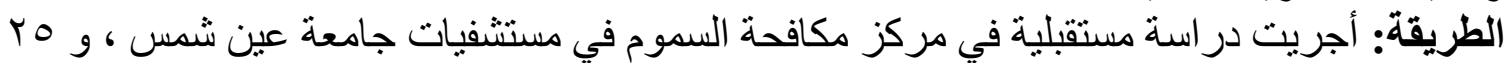

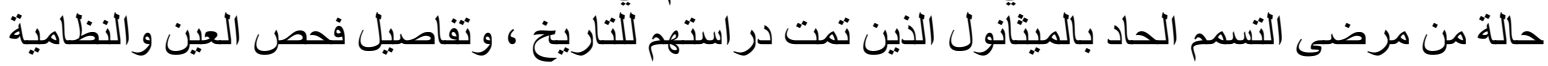

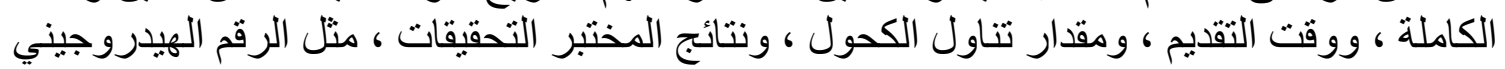

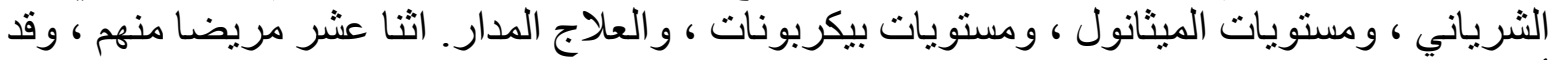

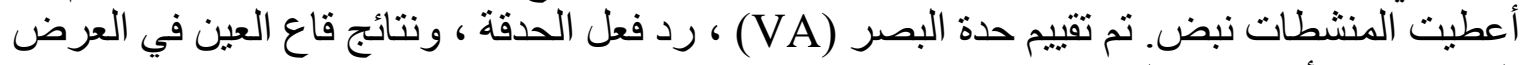

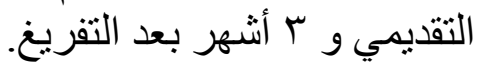
النتائج: تم عن طريق اختبار مربع تشي ، اختبار فيثر الدقيق واختبار t المستقل باستخدام برنامج

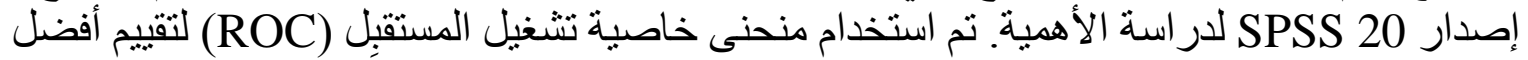
نقطة قطع مع منطقة تحت المنحنى (AUC) و (APP) ، و الحساسية ، و النوعية ، و والقيمة التنبؤية الإيجابية (PPV) و القيمة التنبؤية السلبية (PPV) الاستتناج: يعتبر الرقم الهيدروجيني للام عند القبول مؤشر ا ممتاز اللتنائج المرئية النهائية في التهاب

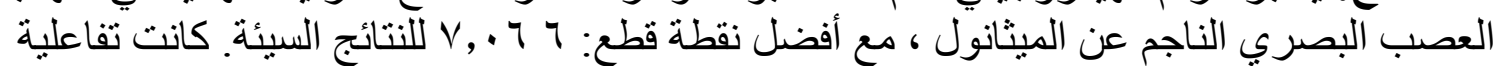

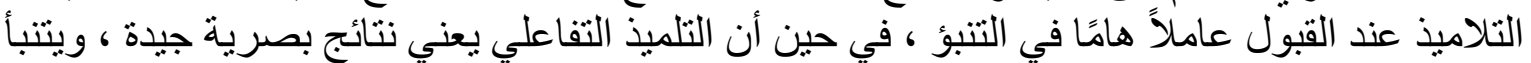

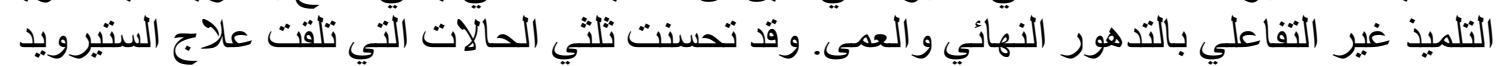

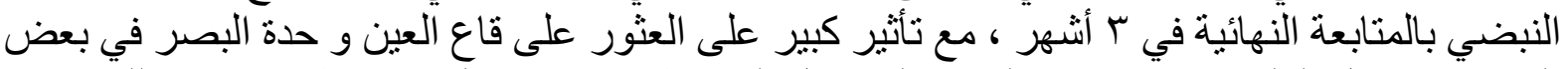

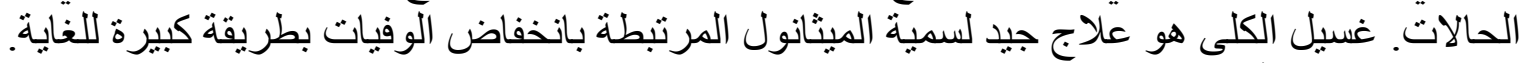

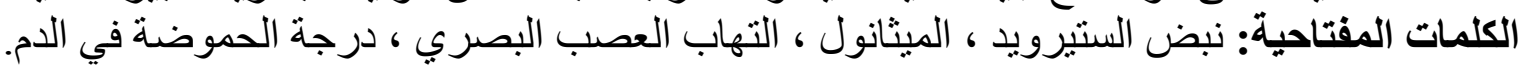

